\title{
Effect of Chahuang ointment on prevention of phlebitis from peripherally inserted central catheter: randomized clinical trial*
}

\author{
Efeito da pomada Chahuang na prevenção de flebite de cateter central \\ inserido perifericamente: ensaio clínico randomizado \\ Efecto de la pomada de Chahuang en la prevención de la flebitis por catéter \\ central insertado periféricamente: ensayo clínico aleatorizado
}

How to cite this article:

Wang X, Lv X, Zhang J, Wang Y. Effect of Chahuang ointment on prevention of phlebitis from peripherally inserted central catheter: randomized clinical trial. Rev Esc Enferm USP. 2021;55:e03680. doi: https://doi.org/10.1590/S1980-220X2019008003680

\section{(iD) Xian Wang ${ }^{1}$ \\ (iD) Xiang Lv' \\ (iD) Jie Zhang ${ }^{1}$ \\ iD Yan Wang ${ }^{1}$}

* Extracted from the monography: "Effect of Chahuang ointment on prevention of phlebitis from peripherally inserted central catheter: randomized clinical trial",

Shanghai Municipal Hospital of Traditional Chinese Medicine, Shanghai University of Traditional Chinese Medicine, 2018.

1 Shanghai University of Traditional Chinese Medicine, Shanghai Municipal Hospital of Traditional Chinese Medicine, Nursing Department, Shanghai, China.

2 Shanghai University of Traditional Chinese Medicine, Shanghai Municipal Hospital of Traditional Chinese Medicine, Oncology Department, Shanghai, China.
Corresponding author:

Xian Wang

Shanghai Municipal Hospital of

Traditional Chinese Medicine

Shanghai University of Traditional

Chinese Medicine

274 Middle Zhijiang Road,

200071 - Shanghai, China

0560@szy.sh.cn

\begin{abstract}
Objective: To assess the effect of Chahuang ointment, a Chinese herbal ointment, on the prevention of phlebitis in patients with peripherally inserted central catheters. Method: This was a multicenter randomized controlled trial, with 171 eligible patients randomly assigned into one of three groups: the Chahuang ointment group, the Mucopolysaccharide Polysulfate cream group, and the control group. The degrees of vein injuries at 72 hours after peripherally inserted central catheter insertion were the primary outcome. Secondary outcomes were the vascular wall thickness, tissue edema and microthrombus evaluated by Color Doppler Flow Imaging, the vascular endothelial growth factor, and endothelin-1 (ET-1) expression in vivo. Results: Compared with the control group, the Chahuang ointment group showed significantly lower incidence of postoperative phlebitis, tissue edema, and microthrombus at 72 hours after peripherally inserted central catheter insertion (all $\mathrm{P}<0.01$ ). The VEGF and ET-1 expression were significantly inhibited in the Chahuang ointment group after 3 days of treatment (both $\mathrm{P}<0.01)$. There were no statistical differences in the degree of vein injuries, microthrombus, or tissue edema between the Chahuang ointment and mucopolysaccharide polysulfate groups (all $\mathrm{P}>0.05$ ). Conclusion: Chahuang ointment was shown to provide effective prevention and protection against phlebitis after peripherally inserted central catheter insertion.

China Trials Registry: ChiCTR-IIR-16009341.
\end{abstract}

\section{DESCRIPTORS}

Medicine, Chinese Traditional; Catheterization, Peripheral; Phlebitis; Edema; Thrombosis; Nursing. 


\section{INTRODUCTION}

A peripherally inserted central catheter (PICC) is a flexible catheter inserted into the superior or inferior vena cava via an upper or lower extremity peripheral vein ${ }^{(1)}$. In China, PICC placement in cancer patients is usually performed by qualified nurses as a vascular pathway for patients with long-term infusion and chemotherapy ${ }^{(2)}$. Compared with surgically inserted central catheters, PICC has higher rates of insertion success ${ }^{(3)}$ and a longer retention time of up to 12 month $^{(4)}$. Although a PICC is an effective intravenous infusion route, complications such as mechanical phlebitis and thrombosis after catheterization often lead to unplanned PICC withdrawal ${ }^{(5)}$. A Brazilian study showed that the rate of catheter-related complications ranged between $41 \%$ and $50.8 \%{ }^{(6)}$, whereas a study in Japan revealed lower rates between $2.9 \%$ and $31.7 \%{ }^{(7)}$. In China, research found that the incidence of phlebitis after paracentesis was $3.1 \%$ to $24 \%{ }^{(8)}$, amongst which the rate of mechanical phlebitis was as high as $15.15 \%-17.0 \%$. Mechanical phlebitis usually occurs $8-10 \mathrm{~cm}$ above the puncture point within 5 days, and especially within 48 to 72 hours, after catheter insertion ${ }^{(9)}$. The incidence of phlebitis increases patient pain and extends hospitalization. Serious complications, such as deep venous thrombosis and sepsis, can also arise from mechanical phlebitis ${ }^{(10-11)}$. The latter stimulates vascular endothelial cells, platelets, and basophils, leading to the release of vascular endothelial growth factor (VEGF) and some inflammatory factors (such as CRP, TNF- $\alpha, \mathrm{ET}-1$ ) ${ }^{(12)}$. These inflammatory changes can induce purpura, erythema, and blisters, causing also serious tissue necrosis or ulcers in the skin tissue around the puncture site.

Previous research has found that mucopolysaccharide polysulfate (MPS) can relieve pain, swelling, hematoma, and inflammation after catheter insertion. With a high cure rate of $90 \%$, MPS is an ideal candidate for in-clinic treatment of phlebitis and thrombosis after PICC insertion ${ }^{(13-14)}$. However, MPS cream is a relatively cumbersome treatment, requiring repeated applications and subsequent massage. Moreover, MPS cream may cause some adverse effects including local skin reaction or contact dermatitis ${ }^{(15)}$.

Traditional Chinese medicine (TCM) plays an important role in health care and has been shown to have positive effects on external therapy ${ }^{(16)}$. Since 2010, the intravenous infusion groups in Shanghai Municipal Hospital of Traditional Chinese Medicine have used Chahuang ointment, a traditional Chinese compound medicine, to treat mechanical phlebitis after PICC insertion. Chahuang ointment contains Curcumae longae rhizome, Rhei radix et rhizoma, Phellodendri chinensis cortex, Atractylodis rhizoma, Magnoliae officinalis cortex, Citri reticulatae pericarpium, Glycyrrhiza radix et rhizoma, Arisaematis rhizoma, Angelicae dahuricae radix, and Trichosanthis radix, mixed with green tea. The curcumin and Rhubarb extracts can dissipate blood stasis and have an analgesia effect, according to TCM. Other herbs included in the formula commonly clear away heat and dampness and activate blood circulation to remove stasis. Green tea contains catechins, flavonoids, and other ingredients that may improve the dismutase activity, resulting in better radical scavenging and inhibition of platelet aggregation ${ }^{(17-18)}$.

During 2010 and 2012, 45 patients were treated with Chahuang ointment to relieve mechanical phlebitis. The results indicated that Chahuang ointment has the potential to prevent mechanical phlebitis in patients with PICC. However, the validity of the study was limited by its small sample size. Therefore, we designed a multicenter, randomized controlled trial (RCT) to evaluate the safety and efficacy of Chahuang ointment in the prevention of mechanical phlebitis after PICC insertion. We expected Chahuang ointment to be an effective alternative therapy for patients with mechanical phlebitis.

\section{METHOD}

\section{Design OF STUdy}

This is a multicenter, randomized, controlled clinical trial. Patients were enrolled from four Tertiary A hospitals in China, including Shanghai Municipal Hospital of Traditional Chinese Medicine, Shanghai Seventh People's Hospital, Jiangsu Second Hospital, and Zhengzhou Hospital of Traditional Chinese Medicine. The trial was conducted between December 2014 and November 2018. Patients receiving a PICC were randomly assigned into three groups, the Chahuang ointment group ( $\mathrm{CHO}$ group), the mucopolysaccharide polysulfate cream group (MPS group), and the control group.

\section{INCLUSION CRITERIA}

The inclusion criteria for patients in this study were as follows: (1) older than 18; (2) inpatient; (3) can communicate orally; (4) affected by vascular conditions which demand PICC intervention; (5) has normal coagulation function; (6) using traditional PICC method; (7) successful first catheterization attempt.

\section{EXCLUSION CRITERIA}

The exclusion criteria were as follows: patients with contraindications to tube, such as history of vascular surgery, skin rash, and coagulant function abnormality.

\section{Data collection}

\section{MATERIALS}

The PICCs used in this study were four French threeway valve type catheters (Bard Access Systems, Inc., USA). PICC sterile puncture bags were provided by various hospital disinfection supply centers.

The Chahuang ointment was made by technicians at the Shanghai Municipal Hospital. Powder of Curcumae longae rhizome (25g), Rhei radix et rhizoma (25g), Phellodendri chinensis cortex (25g), Atractylodis rbizoma (10g), Magnoliae officinalis cortex (10g), Citri reticulatae pericarpium (10g), Glycyrrbiza radix et rhizoma (10g), Arisaematis rbizoma (10g), Angelicae daburicae radix (25g), Trichosanthis radix (50g), and sesame oil $(200 \mathrm{~g})$ were mixed, heated to melt the resulting 
yellow petroleum jelly, and made into a kind of golden yellow ointment. Green tea bags ( $1.5 \mathrm{~g} / \mathrm{bag})$ were soaked in $100 \mathrm{ml}$ water for $30 \mathrm{~min}$ and boiled for 20 minutes. Finally, an equal volume of self-prepared golden yellow ointment and green tea were added to create the Chahuang ointment $(20 \mathrm{~g} / \mathrm{box}$, shelf-life: 12 months).

Medinova AG manufactures Hirudoid ${ }^{\circledR}$ inunction, whose active ingredient is mucopolysaccharide polysulfate (No. H20110926, 14 g/branch; Shelf life: 60 months).

\section{INTERVENTIONS}

\section{Chahuang ointment (CHO) Group}

Patients in the $\mathrm{CHO}$ group used Chahuang ointment the day after PICC insertion, with the same conventional nursing plan as the control group. The ointment was applied evenly on a disposable cotton pad $(8 \mathrm{~cm} \times 15 \mathrm{~cm})$ about 2 $\mathrm{mm}$ thick and covered with an outer permeable membrane. Chahuang ointment was applied along the vein for four hours, from the outer permeable membrane to the central to the deltoid muscle. It was applied twice a day (at $8 \mathrm{AM}$ and 4 PM) for three consecutive days.

\section{Mucopolysaccharide Polysulfate cream (MPS) GROUP}

Patients in the MPS group were treated with the mucopolysaccharide polysulfate cream based on the same conventional nursing as the control group. The mucopolysaccharide polysulfate cream was applied to the punctured veins along about $5 \mathrm{~cm}$. The cream around the applied area was about $2 \mathrm{~mm}$ thick, from the central to the deltoid muscle. Considering the patients' pain tolerance, they were asked to gently massage the skin using circular motions for three minutes until the cream was completely absorbed each time. The mechanical force and friction were suited to each patient's sensitivity. The mucopolysaccharide polysulfate cream was applied once every three hours a day for three consecutive days.

\section{Control group}

Conventional nursing, which includes conventional observation, basic nursing, and health education, was provided to patients in the control group from Day 1 to Day 3 after PICC insertion. Experienced nurses changed the wound dressing 24 hours after catheter insertion, strictly implemented the antiseptic technique, and verified the puncture site for redness, oozing or exudation. The dressing should be changed promptly at the first sign of the latter. Nurses were also required to encourage patients to try to keep the puncture site clean and dry, not to tear off the dressing carelessly, and to avoid excessive movement of the arm on the PICC side.

\section{OutCome MEASUREMENTS}

\section{Primary outcomes}

The primary outcomes were symptoms of the local venous performance, including the presence of phlebitis, the clinical manifestations of phlebitis, time, and severity at 72 hours after surgery. The phlebitis evaluation standards of the Intravenous Nurses Society (INS) were used to classify the degree of the vein injuries $^{(19)}$ into Class 0: no symptoms; Class I: piercing pain, redness, swelling in the puncture site, but no hard knot was reached along the vein; Class II: piercing pain, redness, swelling in the puncture site, and a varicose vein can be touched but without any hard knot; Class III: piercing pain, redness, swelling in the puncture site, and varicose veins could be touched with hard knots. Two nurses with extensive experience in post-operative care of PICC patients conducted these evaluations and recorded the results in the case report forms (CRFs). They received a standardized training in the methods of evaluation prior to the experiment commencement.

\section{SeCOndARY OUtCOMES}

Symptoms of the local venous injuries at 24 hours after surgery were evaluated as the secondary outcomes. Color Doppler Flow Imaging (CDFI) was used to observe the thickness of the blood vessel wall around the puncture site, the incidence of tissue edema, and microthrombus. Full-time doctors in the vascular ultrasound team did the CDFI tests before, 24 hours after, and 72 hours after the PICC insertion, with a high-frequency linear array probe (SL3116 10 to 22 $\mathrm{MHz}$ ) and $22 \mathrm{MHz}$ of probe frequency. Each patient had 2.0 $\mathrm{ml}$ of venous blood drawn for analysis before, 24 hours after, and 72 hours after PICC insertion. The blood samples were centrifuged for $10 \mathrm{~min}$ at $3000 \mathrm{rpm}$ to obtain the separated serum and then stored at $-20^{\circ} \mathrm{C}$. The laboratory technician then used the enzyme-linked immunosorbent assay (ELISA, Shanghai Golden Field Medical Inspection Co, LTD) to test the expression of vascular endothelial growth factor (VEGF) and endothelin-1 (ET-1).

\section{SAMPLE DEFINITION}

Based on the results of preliminary experiments and the anticipated number of incidents of phlebitis after PICC (P) insertion, we used the formula of the sample number of multiple groups: $N=2 \lambda /\left[2 \sin ^{-1}\left(\mathrm{P}_{\max } 0.5\right)-2 \sin ^{-1}\left(\mathrm{P}_{\min }{ }^{0.5}\right)\right]$, where $\mathrm{Pmax}=95 \%, \mathrm{Pmin}=63 \%, \alpha=0.05, \beta=0.10, \lambda=12.65$. Therefore, 44 patients should be recruited for each group. By factoring in a dropout rate of $30 \%$ according to Cohen's $\mathrm{d}=$ 0.8 group difference detection amount, we planned to recruit 57 patients for each group and a total of 171 participants for all three groups.

A random sequence was generated in Microsoft Excel and used to randomly assign patients into three groups. The random numbers and group assignments were kept in a sealed opaque envelope. An independent researcher who was not involved in the study kept the sealed envelopes containing the patients' treatment information. When a new patient was enrolled, the researcher opened the next lowest numbered envelope to reveal the patient's treatment assignment.

\section{Data ANALYSIS}

Analyses were conducted with both the 'Intention-totreat' (ITT) and the 'Per-protocol population' (PP) methods. 
All data was analyzed with the Statistical Package for Social Science (SPSS, Version 24.0). To compare the phlebitis severity level, we first used Kruskal Wallis Test $\mathrm{H}$ to rank whether differences existed between the three groups. When differences were found, we used Nemenyi analysis to analyze the between-group differences. Vascular wall thickness, VEGF expression, and ET-1 expression were expressed as mean \pm standard deviation. The comparison among the three groups was made with the two-way repeated measures analysis of variance (ANOVA). When there were differences, the Bonferroni test was used for multiple comparisons among the three groups. Incidents of micro thrombus and edema in the three groups were analyzed by Chi-square test.

\section{ETHICAL ASPECTS}

This study was approved by the Ethics Committee of Shanghai Municipal Hospital of Traditional Chinese Medicine (No. 2013SHL-KY -10). All patients provided their Signed Informed Consent Forms before the trial. This clinical trial was registered at the Chinese Clinical Trial
Registry (http://www.chictr.org.cn/) with the registration number ChiCTR-IIR-16009341. There were no differences in the materials, treatment or guidance provided to the researchers in the four hospitals.

\section{RESULTS}

\section{BASELINE PATIENT CHARACTERISTICS}

From December 2014 to November 2018, 171 patients from four hospitals were enrolled in this trial $(P>0.05)$. Figure 1 shows a flow chart for the trial. In the $\mathrm{CHO}$ group, 5 patients lost interest and withdrew during the trial. In the MPS group, 5 patients were unsatisfied and dropped out of the trial. One patient had an allergic reaction and was thus excluded from the trial. In the control group, 7 patients lost interest and voluntarily withdrew from the trial. Therefore, 171 cases were included in the ITT analysis ( $\mathrm{CHO}$ group, $n=57$; MPS group, $n=57$; Control group, $n=57$ ) and 153 cases were included in the PP analysis (CHO group, $n=52$; MPS group, $n=51$; Control group, $n=50$ ).

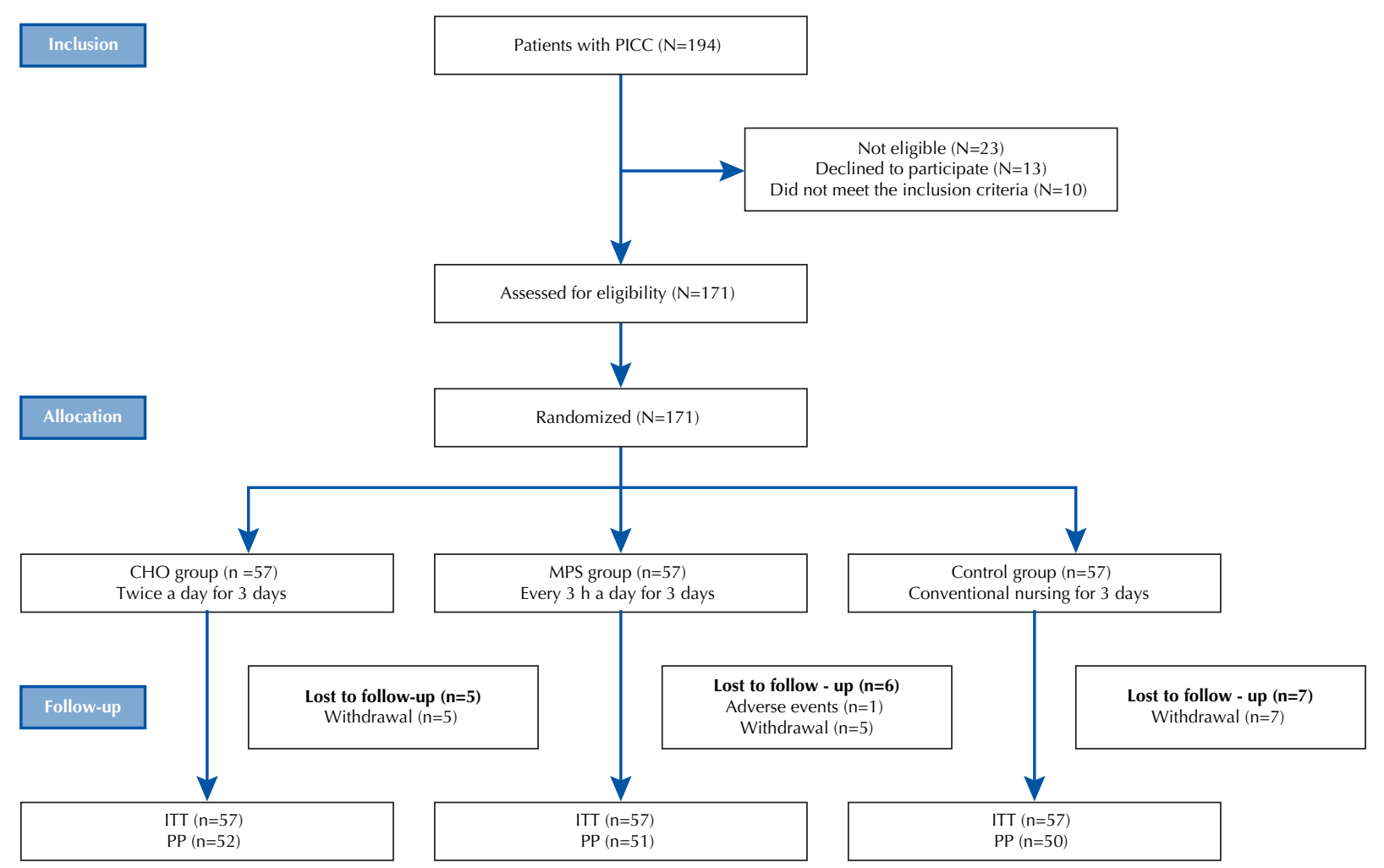

Figure 1 - Flowchart of the trial - Shanghai, China, 2019.

\section{COMPARISON OF VEIN INJURIES IN 3 GROUPS}

Table 1 showed that there was no significant difference among the three groups 24 hours after PICC insertion $(P>0.05)$. There was a statistical difference among the three groups in the degree of the vein injuries at 72 hours after PICC insertion $(P=0.002<0.01)$, but no statistical difference was found in the degree of the vein injuries between the $\mathrm{CHO}$ group and the MPS group $\left(\chi^{2}=0.00, P=1.00>0.05\right)$.
Patients in the CHO and MPS groups had fewer incidents of phlebitis than those in the control group, and the between-group differences were statistically significant (ITT analysis: Control vs $\mathrm{CHO}, \chi^{2}=9.17, P=0.01$; Control vs MPS, $\left.\chi^{2}=8.97, P=0.01\right)$. The results indicated that both Chahuang ointment and mucopolysaccharide polysulfate cream could effectively prevent phlebitis and protect blood vessels in patients receiving PICC insertion. 


\section{COMPARISON OF THE CDFI RESULTS IN THREE GROUPS}

Table 1 and Table 2 show the incidents of microthrombus formation and tissue edema among the three groups, as well as changes of the blood vessel wall thickness 72 hours after PICC insertion. As in the results for vein injuries, there was no difference in these outcome measurements among the three groups 24 hours after PICC insertion $(P>0.05)$. However, we found statistically significant differences in the incidence of microthrombus formation and tissue edema among the three groups at 72 hours after catheter insertion (both $P=0.001<0.01$ ). Pairwise comparison showed that, compared with the control group, there was less microthrombus formation and tissue edema in patients in the $\mathrm{CHO}$ and MPS groups, and the blood vessel walls around the puncture site of patients in those two groups were thinner (respective ITT analysis for microthrombus formation rate: Control vs $\mathrm{CHO}, \chi^{2}=9.21, P=0.002$, Control ws MPS, $\chi^{2}=7.60$, $P=0.006$; ITT analysis for tissue edema rate: Control vs $\mathrm{CHO}, \chi^{2}=10.61 P=0.001$; Control vs MPS, $\chi^{2}=9.33 P=0.002$; and ITT analysis for blood vessel wall thickness: Control vs CHO, $P<0.001$; Control vs MPS, $P=0.001)$. Moreover, no statistical difference was found in the incidents of microthrombus formation $\left(\chi^{2}=0.101 \mathrm{P}=0.751>0.05\right)$, the incidents of tissue edema $\left(\chi^{2}=0.046 P=0.830>0.05\right)$ or in the thickness of blood vessel walls $(P=0.276>0.05)$ between the $\mathrm{CHO}$ group and the MPS group.

\section{COMPARISON OF SERUM VEGF AND ET-1 leVELS IN 3 GROUPS}

A positive correlation was found between serum VEGF or ET-1 concentration and acute vascular injuries, so that an increase in the VEGF or ET-1 concentration was always accompanied with more serious acute vascular injuries. Table 2 shows that the serum VEGF and ET- 1 concentrations of patients at 24 hours after PICC insertion were significantly higher than the baseline levels, but with no statistical differences among the three groups (respectively $\mathrm{P}=0.861$ and $\mathrm{P}=0.117>0.05)$. Significant changes, however, did appear 72 hours after catheter insertion (both $P<0.01$ ).

Compared with the control group, the serum ET-1 levels of patients in the $\mathrm{CHO}$ and MPS groups were significantly lower (ITT analysis: Control vs $\mathrm{CHO}, P=0.011<0.05$; Control vs MPS, $P=0.001<0.01)$. Similar results were found in the serum VEGF levels. However, there was no statistical difference when comparing these serum levels between the $\mathrm{CHO}$ group and MPS group (both $P>0.05$ ).

Table 1 - The comparisons of vein injuries, microthrombus, and tissue edema in three groups at 24 and 72 hours after PICC - Shanghai, China, 2019.

\begin{tabular}{|c|c|c|c|c|c|c|c|c|c|c|c|c|c|}
\hline \multirow[b]{2}{*}{ Groups } & \multirow[b]{2}{*}{$\mathbf{n}$} & \multicolumn{6}{|c|}{ Vein injuries } & \multicolumn{3}{|c|}{ Microthrombus } & \multicolumn{3}{|c|}{ Tissue edema } \\
\hline & & $\begin{array}{c}\text { Class } 0 \\
\mathrm{~N}\end{array}$ & $\begin{array}{c}\text { Class I } \\
\mathrm{N}\end{array}$ & $\begin{array}{c}\text { Class II } \\
\mathbf{n}\end{array}$ & $\begin{array}{c}\text { Class III } \\
\mathbf{n}\end{array}$ & $\begin{array}{c}\chi^{2} \\
\text { value }\end{array}$ & P value & $\begin{array}{c}\text { Occurred }^{c} \\
\mathrm{n}(\%)\end{array}$ & $\chi^{2}$ value & $P$ value & $\begin{array}{c}\text { Occurred c } \\
n(\%)\end{array}$ & $\begin{array}{c}\chi^{2} \\
\text { value }\end{array}$ & $P$ value \\
\hline \multicolumn{14}{|l|}{ PICC $24 \mathrm{hr}$} \\
\hline \multicolumn{14}{|l|}{ ITT } \\
\hline $\mathrm{CHO}$ group & 57 & 51 & 5 & 1 & 0 & & & 25(43.86) & & & $56(98.25)$ & & \\
\hline MPS group & 57 & 51 & 4 & 2 & 0 & & & $24(42.11)$ & & & $54(94.74)$ & & \\
\hline $\begin{array}{l}\text { Control } \\
\text { group }\end{array}$ & 57 & 47 & 4 & 6 & 0 & 1.97 & $\underset{\mathrm{a}}{0.373}$ & 28(49.12) & 0.61 & $\underset{\mathrm{b}}{0.736}$ & $55(96.49)$ & $1.07^{*}$ & $0.872^{\mathrm{b}}$ \\
\hline \multicolumn{14}{|l|}{ PP } \\
\hline $\mathrm{CHO}$ group & 52 & 46 & 5 & 1 & 0 & & & 25(48.08) & & & 51(98.08) & & \\
\hline MPS group & 51 & 45 & 4 & 2 & 0 & & & $24(47.06)$ & & & 48(94.12) & & \\
\hline $\begin{array}{l}\text { Control } \\
\text { group }\end{array}$ & 50 & 40 & 4 & 6 & 0 & 1.83 & $0.401^{\mathrm{a}}$ & $28(56.00)$ & 0.97 & $0.617^{b}$ & 48(96.00) & $1.11^{*}$ & $0.613^{b}$ \\
\hline \multicolumn{14}{|l|}{ PICC $72 \mathrm{hr}$} \\
\hline \multicolumn{14}{|l|}{ ITT } \\
\hline $\mathrm{CHO}$ group & 57 & 54 & 3 & 0 & 0 & & & $5(8.77)$ & & & $14(24.56)$ & & \\
\hline MPS group & 57 & 54 & 2 & 1 & 0 & & & $6(10.53)$ & & & $15(26.32)$ & & \\
\hline $\begin{array}{l}\text { Control } \\
\text { group }\end{array}$ & 57 & 44 & 8 & 5 & 0 & 12.09 & $0.002^{\mathrm{a}}$ & 18(31.58) & 13.04 & $0.001^{\mathrm{b}}$ & $31(54.39)$ & 14.02 & $0.001^{b}$ \\
\hline \multicolumn{14}{|l|}{ PP } \\
\hline $\mathrm{CHO}$ group & 52 & 49 & 3 & 0 & 0 & & & $5(9.62)$ & & & $14(26.92)$ & & \\
\hline MPS group & 51 & 48 & 2 & 1 & 0 & & & $6(11.76)$ & & & $15(29.41)$ & & \\
\hline $\begin{array}{l}\text { Control } \\
\text { group }\end{array}$ & 50 & 37 & 8 & 5 & 0 & 12.88 & $0.002^{a}$ & 18(36.00) & 14.13 & $0.001^{b}$ & $31(62.00)$ & 16.24 & $<0.001^{b}$ \\
\hline
\end{tabular}

Note: ${ }^{\mathrm{a}}$ Kruskal Wallis Test; ${ }^{\mathrm{b}}$ Chi-square test; ${ }^{\mathrm{c}} n$ (\%); *: Fisher's exact test (ITT: $n=171$; PP: $n=153$ )

Abbreviations: $\mathrm{PICC}=$ Peripherally inserted central catheter; $\mathrm{CHO}=$ Chahuang ointment; $\mathrm{MPS}=$ Mucopolysaccharide polysulfate cream. 
Table 2 - The comparisons of blood vessel wall thickness, serum levels of VEGF and ET-1 in three groups at different moments - Shanghai, China, 2019.

\begin{tabular}{|c|c|c|c|c|c|c|c|c|c|c|}
\hline \multirow{2}{*}{ Groups } & \multicolumn{4}{|c|}{ Blood vessel wall thickness (mm) } & \multicolumn{3}{|c|}{ VEGF (pg/ml) } & \multicolumn{3}{|c|}{ ET-1 (pg/ml) } \\
\hline & $n$ & Baseline & $24 \mathrm{~h}$ & $72 \mathrm{~h}$ & Baseline & $24 \mathrm{~h}$ & $72 \mathrm{~h}$ & Baseline & $24 \mathrm{~h}$ & $72 \mathrm{~h}$ \\
\hline \multicolumn{11}{|l|}{ ITT } \\
\hline $\begin{array}{l}\mathrm{CHO} \\
\text { group }\end{array}$ & 57 & $0.32 \pm 0.02$ & $\begin{array}{c}0.54 \pm \\
0.07\end{array}$ & $0.47 \pm 0.06$ & $44.40 \pm 22.15$ & $60.81 \pm 21.05$ & $35.05 \pm 16.84$ & $5.31 \pm 3.92$ & $7.62 \pm 4.70$ & $5.67 \pm 3.59$ \\
\hline MPS group & 57 & $0.33 \pm 0.02$ & $\begin{array}{c}0.57 \pm \\
0.06\end{array}$ & $0.48 \pm 0.05$ & $45.19 \pm 19.73$ & $58.72 \pm 18.22$ & $33.10 \pm 14.94$ & $5.19 \pm 2.90$ & $7.08 \pm 5.03$ & $5.34 \pm 3.16$ \\
\hline $\begin{array}{l}\text { Control } \\
\text { group }\end{array}$ & 57 & $0.33 \pm 0.03$ & $\begin{array}{c}0.57 \pm \\
0.08\end{array}$ & $\begin{array}{c}0.52 \pm \\
0.07\end{array}$ & $43.33 \pm 20.87$ & $59.68 \pm 24.75$ & $47.24 \pm 14.97$ & $5.06 \pm 2.78$ & $8.84 \pm 3.91$ & $7.81 \pm 4.01$ \\
\hline F value & & 1.46 & 1.76 & 12.06 & 0.10 & 0.15 & 13.79 & 0.08 & 2.19 & 8.64 \\
\hline$P$ value & & 0.236 & 0.177 & $<0.001$ & 0.894 & 0.861 & $<0.001$ & 0.924 & 0.117 & $<0.001$ \\
\hline \multicolumn{11}{|l|}{ PP } \\
\hline $\begin{array}{l}\mathrm{CHO} \\
\text { group }\end{array}$ & 52 & $0.32 \pm 0.02$ & $\begin{array}{c}0.55 \pm \\
0.07\end{array}$ & $0.47 \pm 0.05$ & $44.09 \pm 21.59$ & $60.07 \pm 21.32$ & $34.38 \pm 17.18$ & $5.18 \pm 3.92$ & $7.79 \pm 4.92$ & $5.78 \pm 3.58$ \\
\hline MPS group & 51 & $0.32 \pm 0.02$ & $\begin{array}{c}0.57 \pm \\
0.06\end{array}$ & $0.48 \pm 0.05$ & $45.22 \pm 18.34$ & $59.29 \pm 18.33$ & $33.66 \pm 15.26$ & $5.48 \pm 2.84$ & $7.06 \pm 5.04$ & $5.33 \pm 2.96$ \\
\hline $\begin{array}{l}\text { Control } \\
\text { group }\end{array}$ & 50 & $0.33 \pm 0.03$ & $\begin{array}{c}0.56 \pm \\
0.08\end{array}$ & $\begin{array}{c}0.52 \pm \\
0.06\end{array}$ & $44.36 \pm 19.33$ & $58.77 \pm 24.32$ & $46.65 \pm 15.36$ & $4.69 \pm 2.54$ & $8.91 \pm 3.98$ & $7.92 \pm 4.23$ \\
\hline F value & & 1.03 & 0.98 & 7.52 & 0.04 & 0.05 & 10.72 & 0.81 & 1.95 & 7.43 \\
\hline$P$ value & & 0.361 & 0.376 & 0.001 & 0.960 & 0.953 & $<0.001$ & 0.447 & 0.148 & 0.001 \\
\hline
\end{tabular}

Note: Two-way repeated measures ANOVA (ITT: $n=171$; PP: $n=153$ )

Abbreviations: VEGF=Vascular endothelial growth factor; ET-1=Endothelin-1; CHO= Chahuang ointment; MPS=Mucopolysaccharide polysulfate cream

\section{SAFETY}

In the MPS group, one patient had an allergic reaction, resulting in PICC removal the next day. Patients in the other two groups reported no adverse events.

\section{DISCUSSION}

This is a multi-center RCT designed to evaluate the safety and effectiveness of a Chinese external medicine, Chahuang ointment, for patients receiving PICC insertion. The results showed that, compared with patients with conventional nursing, patients treated with Chahuang ointment and mucopolysaccharide polysulfate cream had a lower occurrence of mechanical phlebitis and better vessel conditions around the puncture site after PICC insertion. Though there were no significant statistical differences in the measurements between the CHO and MPS groups, the findings in this study supports the curative effect of Chahuang ointment, showing that it can be an alternative therapy for mucopolysaccharide polysulfate cream, whose use is complex and time-consuming. As a natural medicine, the Chahuang ointment has fewer side effects when compared with the mucopolysaccharide polysulfate cream, which is contraindicated for patients who are highly allergic to cream or heparin ${ }^{(20)}$.

The results of this trial show that PICC-induced acute vascular injuries occurred within 24 hours, which is consistent with previous research results ${ }^{(21)}$. The incidence of microthrombus and tissue edema reduced after 72 hours in
$\mathrm{CHO}$ and MPS groups and the concentrations of VEGF and ET-1 significantly decreased after 72 hours. This indicates that Chahuang ointment was equal to or slightly better than mucopolysaccharide polysulfate cream in its ability to inhibit vascular inflammation and alleviate edema. Acute inflammation commonly appeared from a few minutes to 24 hours after the procedure, with potential to develop into chronic inflammation ${ }^{(22)}$ within several more days. The concentrations of serums VEGF and ET-1 play an important role in acute endothelial injuries ${ }^{(23-24)}$.

The pathogenesis of phlebitis is similar to that of "bad veins" as recorded in the ancient Chinese medical literature. According to traditional Chinese medicine, it is caused by drug stimulation or puncture injury during the process of infusion, which leads to blood stasis and stagnation of $q i$, causing redness, swelling, and pain in local sites. The main effective components of the Chahuang ointment are Curcumae longae rbizoma, Rhei radix et rbizoma, and green tea extracts, which are effective at clearing heat, reducing swelling, and relieving pain. During the 3-day treatment, the external application of Chahuang ointment had impressive effects on mechanical phlebitis; this is mainly because Chinese herbal medicine can directly exert its effects on punctured veins through transdermal absorption.

There are some limitations to this trial. This is possibly the first multi-center RCT to evaluate the effects of Chahuang ointment on patients receiving PICC insertion, and the small sample size of each group in the four hospitals may imply 
patient heterogeneity. In a further study, we can make full use of these results and recruit more patients in different centers in China to perform an overall assessment of the effects and safety of Chahuang ointment. Another limitation was the blinding method. Due to the different appearances of the two interventions, patients and nurses could not be blinded to group assignment, which may have caused some bias. Thus, we tried to maintain the principle of task separation to avoid unnecessary communication among the researchers during the trial.

\section{CONCLUSION}

This study has shown that Chahuang ointment can effectively prevent the development of mechanical phlebitis after PICC insertion. Our study has expanded the scope of clinical application of a traditional Chinese medicine as a nursing technique. This TCM nursing procedure is safe and effective. Therefore, it is worth considering Chahuang ointment as a treatment option for the prevention of mechanical phlebitis in patients receiving PICC.

\section{RESUMO}

Objetivo: Avaliar o efeito da pomada Chahuang, uma pomada à base de ervas chinesas, na prevenção de flebite em pacientes com cateter central de inserção periférica. Método: Este foi um estudo multicêntrico randomizado controlado, com 171 pacientes elegíveis aleatoriamente designados em um de três grupos: o grupo de pomada Chahuang, o grupo de creme de polissulfato de mucopolissacarídeo e o grupo de controle. Os graus de lesões das veias em 72 horas após a inserção do cateter central perifericamente inserido foram o resultado primário. Os desfechos secundários foram a espessura da parede vascular, edema tecidual e microtrombos avaliados por Color Doppler Flow Imaging, o fator de crescimento endotelial vascular e a expressão da endotelina-1 (ET-1) in vivo. Resultados: Comparado com o grupo controle, o grupo de pomada Chahuang apresentou incidência significativamente menor de flebite pós-operatória, edema de tecido e microtrombos 72 horas após a inserção do cateter central inserido perifericamente (todos $\mathrm{P}<0,01$ ). A expressão de VEGF e ET-1 foi significativamente inibida no grupo de pomada Chahuang após 3 dias de tratamento (ambos $\mathrm{P}<0,01$ ). Não houve diferenças estatísticas no grau de lesões das veias, microtrombos ou edema de tecido entre os grupos de pomada de Chahuang e polissulfato de mucopolissacarídeo (todos $\mathrm{P}>$ 0,05). Conclusão: A pomada Chahuang demonstrou fornecer prevenção e proteção eficazes contra flebite após a inserção do cateter central perifericamente inserido.

Registro de ensaios da China: ChiCTR-IIR-16009341.

\section{DESCRITORES}

Medicina Tradicional Chinesa; Cateterismo Periférico; Flebite; Edema; Trombose; Enfermagem.

\section{RESUMEN}

Objetivo: Evaluar el efecto de la pomada Chahuang, una pomada herbal china, sobre la prevención de la flebitis en pacientes con catéteres centrales insertados periféricamente. Método: Este fue un ensayo controlado aleatorio multicéntrico, con 171 pacientes elegibles asignados al azar en uno de tres grupos: el grupo de ungüento Chahuang, el grupo de crema de polisulfato de mucopolisacárido y el grupo de control. Los grados de lesiones de las venas a las 72 horas después de la inserción del catéter central insertado periféricamente fueron el resultado primario. Los resultados secundarios fueron el grosor de la pared vascular, el edema tisular y el microtrombo evaluados por imágenes de flujo con Doppler en color, el factor de crecimiento endotelial vascular y la expresión de endotelina-1 (ET-1) in vivo. Resultados: En comparación con el grupo de control, el grupo de ungüento Chahuang mostró una incidencia significativamente menor de flebitis posoperatoria, edema tisular y microtrombos a las 72 horas después de la inserción del catéter central insertado periféricamente (todos $\mathrm{P}<0,01$ ). La expresión de VEGF y ET-1 se inhibió significativamente en el grupo de pomada de Chabuang después de 3 días de tratamiento (ambos $\mathrm{P}<0,01$ ). No hubo diferencias estadísticas en el grado de lesiones venosas, microtrombos o edema tisular entre los grupos de pomada de Chahuang y polisulfato de mucopolisacárido (todos P>0,05). Conclusión: Se demostró que la pomada de Chahuang proporciona una prevención y protección eficaces contra la flebitis después de la inserción de un catéter central insertado periféricamente.

Registro de ensayos de China: ChiCTR-IIR-16009341.

\section{DESCRIPTORES}

Medicina China Tradicional; Cateterismo Periférico; Flebitis; Edema; Trombosis; Enfermería.

\section{REFERENCES}

1. Kollár G, Alizadeh H, Gulyás E. Nurse style of central vein! Our experience in the peripherally inserted central venous catheter. Orv Hetil. 2017;158(22):856-63. doi: 10.1556/650.2017.30765

2. Park K, Jun HJ, Oh SY. Safety, efficacy, and patient-perceived satisfaction of peripherally inserted central catheters in terminally ill cancer patients: a prospective multicenter observational study. Support Care Cancer. 2016;24(12):4987-92. doi: 10.1007/s00520-016-3360-6

3. Westergaard B, Classen V, Walther-Larsen S. Peripherally inserted central catheters in infants and children-indications, techniques, complications and clinical recommendations. Acta Anaesthesiol Scand. 2013;57(3):278-87. doi: 10.1111/aas.12024

4. Walker G, Todd A. Nurse-led PICC insertion: is it cost effective? Br J Nurs. 2013;22(19):S9-15. doi: http://dx.doi.org/10.12968/bjon.2013.22. Sup19.S9

5. Bertoglio S, Faccini B, Lalli L, Cafiero F, Bruzzi P. Peripherally inserted central catheters (PICCs) in cancer patients under chemotherapy: a prospective study on the incidence of complications and overall failures. J Surg Oncol. 2016;113(6):708-14. doi: 10.1002/jso.24220

6. Gomes AVO, Nascimento MAL. Central venous catheterization in pediatric and neonatal intensive care units. Rev Esc Enferm USP. 2013;47(4):794-800. doi: http://dx.doi.org/10.1590/S0080-623420130000400004

7. Ohki Y, Maruyama K, Harigaya A, Kohno M, Arakawa H. Complications of peripherally inserted central venous catheter in Japanese neonatal intensive care units. Pediatr Int. 2013;55(2):185-9. doi: 10.1111/ped.12033

8. Tian XL, Wang YG, Song LX, Cheng ML, Cheng NN. Adrance in research of prevention and control of PICC-related phlebitis. Chin Clin Nurs. 2015;7(5):452-5. doi: http://dx.doi.org/10.3969/j.issn.1674-3768.2015.05.030 
9. Xu CF, Bao MZ, Ren J. Application of evidence-based nursing in prevention and treatment of complications of PICC catheterization in adults. Chin Gen Pract Nurs. 2014;12(5):410-11. doi: http://dx.doi.org/10.3969/j.issn.1674-4748.2014.05.014

10. Wen J, Yu Q, Chen H, Chen N, Huang S, Cai W. Peripherally inserted central venous catheter-associated complications exert negative effects on body weight gain in neonatal intensive care units. Asia Pac J Clin Nutr. 2017;26(1):1-5. doi: 10.6133/apjcn.112015.07

11. Wang WJ, Zhang T. Integration of traditional Chinese medicine and Western medicine in the era of precision medicine. J Integr Med. 2017;15(1):1-7. doi: 10.1016/S2095-4964(17)60314-5

12. Lu Y, Hao C, He W, Tang C, Shao Z. Experimental research on preventing mechanical phlebitis arising from indwelling needles in intravenous therapy by external application of mirabilite. Exp Ther Med. 2017;15(1)276-82. doi: 10.3892/etm.2017.5347

13. Xu YN, Chen XY, Yuan L, Yang LH. Effect of blue cape skin better on prevention of chemotherapy phlebitis caused by chemotherapy drugs. J Nurs. 2014;21(5):12-4. doi: http://dx.doi.org/10.16460/j.issn1008-9969.2014.05.008

14. Yan YM, Fan QL, Li AQ, Chen JL, Dong FF, Gong M. Treatment of cutaneous injuries of neonates induced by drug extravasation with hyaluronidase and hirudoid. Iran J Pediatr. 2014;24(4):352-8.

15. Guangzong L, Gerhard L, He P, Yang B, Litscher D, Wang L. Experimental study of phlebitis ointment administration in acute superficial thrombophlebitis. Evid Based Complement Alternat Med. 2018;2018:1-11. doi: 10.1155/2018/2983195

16. Zhang J, Shen J, Yin W, Wei X, Wu L, Liu H. The intervention research on treatment by Xianchen to rabbits model of chemotherapeutic phlebitis. Acta Cir Bras. 2016;31(8):549-56. doi: 10.1590/S0102-865020160080000008

17. Ohishi T, Goto S, Monira P, Isemura M, Nakamura Y. Anti-inflammatory Action of Green Tea. Antiinflamm Antiallergy Agents Med Chem. 2016;15(2):74-90. doi: 10.2174/187152301566616091

18. Wan Y. Observation for clinical effect of phellodendron wet compress in treating the phlebitis caused by infusion. Pak J Pharm Sci. 2018;31(3Spec):1099-102.

19. Li J, Fan YY, Xin MZ, Yan J, Hu W, Huang WH, et al. A randomised, controlled trial comparing the long-term effects of peripherally inserted central catheter placement inchemotherapy patients using B-mode ultrasound with modified Seldinger technique versus blind puncture. Eur J Oncol Nurs. 2014;18(1):94-103. doi: 10.1016/j.ejon.2013.08.003

20. Wanitphakdeedecha R, Manuskiatti W, Eimpunth S. The effects of single application of mucopolysaccharide polysulphate (MPS).J Am Acad Dermat. 2007;56(2):AB96. doi: https://doi.org/10.1016/j.jaad.2006.10.450

21. Tan YHG, Tai WLS, Sim C, Ng HLI. Optimising peripheral venous catheter usage in the general inpatient ward: a prospective observational study. J Clin Nurs. 2017;26(1-2):133-9. doi: https://doi.org/10.1111/jocn.13451

22. Pasalioglu KB, Kaya H. Catheter indwell time and phlebitis development during peripheral intravenous catheter administration. Pak J Med Sci. 2014;30(4):725-30.

23. Jacobi J, Tam BYY, Sundram, U, Von Degenfeld G, Blau HM, Kuo CJ, et al. Discordant effects of a soluble VEGF receptor on wound healing and angiogenesis. Gene Ther. 2004;11(3):302-9. doi: 10.1038/sj.gt.3302162

24. Tangkijvanich P, Tam SP, Hal F. Yee Jr HF. Wound-induced migration of rat hepatic stellate cells is modulated by Endothelin-1 through rhokinase-mediated alterations in the acto-myosin cytoskeleton. Hepatology, 2001;33(1):74-80. doi: https://doi.org/10.1053/jhep.2001.20677 